\title{
Phylogenetic Analysis Reveals New Relationships among Members of the Genera Microtetraspora and Microbispora
}

\author{
YUE WANG, ${ }^{*}$ ZHENSHUI ZHANG, AND JISHENG RUAN \\ Microbial Collection and Screen Laboratory, Institute of Molecular and Cell Biology, \\ National University of Singapore, Singapore 119260
}

\begin{abstract}
The 16S rRNA gene sequences of 7 Microbispora strains, 14 Microtetraspora species, 9 Streptosporangium species, and 12 Actinomadura species were determined. A phylogenetic analysis showed that Microtetraspora fusca, Microtetraspora glauca, and Microtetraspora niveoalba formed a coherent cluster with the members of the genus Microbispora. This cluster is distantly related to two other clusters, one of which consists of the Microtetraspora species transferred from the former Actinomadura pusilla group and one of which consists of members of the genus Streptosporangium. Our results show that it is necessary to review the taxonomic definitions of the genera Microtetraspora and Microbispora, which have been separated by a single morphological characteristic, the number of spores on spore chains.
\end{abstract}

The genus Microtetraspora was established by Thiemann et al. (26) in 1968 for actinomycetes characterized by formation of chains of four spores on aerial mycelia. Two species, $\mathrm{Mi}$ crotetraspora glauca and Microtetraspora fusca, were originally proposed. In 1971 Nonomura and Ohara $(13,14)$ described two more species Microtetraspora viridis and Microtetraspora niveoalba. On the basis of the results of chemotaxonomic and DNA-DNA homology analyses Miyadoh et al. (12) found that Microtetraspora viridis clearly differed from the other three Microtetraspora species and resembled the strains belonging to the Actinomadura madurae group. Microtetraspora viridis was therefore transferred to the genus Actinomadura. Recently, Kroppenstedt et al. (7) performed a comprehensive chemical, molecular, and numerical analysis of a large number of Actinomadura and Microtetraspora type strains. These authors obtained substantial evidence that the Actinomadura pusilla group should be reclassified in the genus Microtetraspora.

Although the Microtetraspora pusilla group and the three original Microtetraspora species have very similar chemotaxonomic characteristics, including similar fatty acid and menaquinone profiles (7), there are several lines of evidence which show that these two groups are different. First, a numerical taxonomic analysis revealed that Microtetraspora glauca and Microtetraspora niveoalba are more closely related to Microbispora rosea than to members of the Microtetraspora pusilla group (1). Second, the relative electrophoretic mobilities of the ribosomal AT-L30 proteins of the three original Microtetraspora species ranged from -6.5 to -5.0 , while most of the members of the Microtetraspora pusilla group had relative electrophoretic mobilities ranging from -1.5 to $0.0(15,16,18)$. Third, the three original Microtetraspora species are apparently more closely related to each other than to the species belonging to the Microtetraspora pusilla group on the basis of chemotaxonomic characteristics and DNA-DNA homology data (7, 11).

Goodfellow et al. $(4,5)$ proposed the family Streptosporangiaceae to accommodate the chemically homogeneous genera $\mathrm{Mi}$ crotetraspora, Microbispora, Streptosporangium, Planobispora, Planomonospora, and Spirillospora. These genera are distin-

\footnotetext{
* Corresponding author. Mailing address: Institute of Molecular and Cell Biology, National University of Singapore, 10 Kent Ridge Crescent, Singapore 119260. Phone: 65 7783207. Fax: 657791117. Electronic mail address: mcbwangy@leonis.nus.sg.
}

guished primarily on the basis of morphological characteristics. For example, the genera Microtetraspora and Microbispora are distinguished solely by the number of spores on their spore chains. The almost identical chemotaxonomic patterns of $\mathrm{Mi}$ crotetraspora, Microbispora, and Streptosporangium strains has limited the study of the intra- and intergeneric relationships.

Phylogenetic analyses of $16 \mathrm{~S}$ rRNA gene sequences have been used extensively to resolve relationships among microorganisms at virtually all taxonomic levels $(20,23,24,27-29)$. Stackebrandt et al. analyzed the $16 \mathrm{~S}$ rRNA genes of several Stretosporangium species and described heterogeneity within this genus (23). However, few 16S rRNA gene sequences of other members of the family Streptosporangiaceae were available.

In order to add a phylogenetic dimension to the relationships among Microtetraspora species and the relationships of these organisms with members of closely related genera, we analyzed the 16S rRNA genes of most Microbispora, Microtetraspora, Streptosporangium, and Actinomadura species.

\section{MATERIALS AND METHODS}

Organisms and culture conditions. The actinomycete strains used in this study were purchased from the Japan Collection of Microorganisms (Wako, Japan), the Institute for Fermentation (Osaka, Japan), and the American Type Culture Collection (Rockville, Md.). The strains which we used are listed in Table 1. Cells were cultured in the media described by the suppliers.

Preparation of genomic DNA. Mycelia of actinomycete strains were harvested by centrifugation at $3,600 \times g$ for $5 \mathrm{~min}$ in a model $5410 \mathrm{C}$ microcentrifuge (Eppendorf, Hamburg, Germany). Approximately $200-\mu l$ of wet mycelia was transferred to a $1.5-\mathrm{ml}$ Eppendorf microcentrifuge tube. The mycelia were resuspended in $500 \mu \mathrm{l}$ of lysozyme buffer containing $25 \mathrm{mM}$ Tris-Cl (pH 8.0), 50 $\mathrm{mM}$ glucose, $10 \mathrm{mM}$ EDTA, and $5 \mathrm{mg}$ of lysozyme (Sigma Chemical Co., St. Louis, Mo.) per $\mathrm{ml}$ and incubated at $37^{\circ} \mathrm{C}$ for $30 \mathrm{~min}$. After lysozyme digestion, sodium dodecyl sulfate was added to a final concentration of $1 \%$, and the tubes were incubated at $65^{\circ} \mathrm{C}$ for $30 \mathrm{~min}$. The cell lysate was extracted twice with an equal volume of phenol and once with chloroform-isoamyl alcohol (24:1). The nucleic acid was precipitated with 1 volume of isopropanol at room temperature until a thread-like precipitate appeared. Then the nucleic acid preparation was centrifuged in an Eppendorf microcentrifuge at $14,000 \times g$ for $5 \mathrm{~min}$. The supernatant was decanted, and the tubes were left inverted on a piece of paper towel for $10 \mathrm{~min}$. The nucleic acid was resuspended in $100 \mu \mathrm{l}$ of $10 \mathrm{mM}$ Tris-1 mM EDTA (pH 7.5) containing $100 \mu \mathrm{g}$ of DNase-free RNase A (Sigmal Chemical Co.) per $\mathrm{ml}$ and incubated at $37^{\circ} \mathrm{C}$ for $30 \mathrm{~min}$. Then the nucleic acid was extracted once with phenol-chloroform (1:1), precipitated, and resuspended as described above.

Oligonucleotides used for PCR and sequencing. The two primers used for PCR amplification of nearly complete 16S rRNA genes were 5'TTACCTGAT AGCGGCCGCAGAGTTTGATCCTGGCTCAG3' (nucleotides 8 to 27 of the Escherichia coli 16S rRNA gene) (2) and 5'TACAGGATCCGCGGCCGCTAC GG(C/T)TACCTTGTTACGACTT3' (nucleotides 1492 to 1513) (the underlined sequences are cleavage sites of restriction enzyme NotI). The nonspecific nucleotides on the $5^{\prime}$ side of the NotI site were included for efficient cleavage by 
TABLE 1. Actinomycete strains used

\begin{tabular}{|c|c|c|}
\hline Taxon & Strain & $\begin{array}{l}\text { GenBank nucleo- } \\
\text { tide sequence } \\
\text { assession no. }\end{array}$ \\
\hline Actinomadura atramentaria & IFO $14695^{\mathrm{T} a}$ & U49000 \\
\hline Actinomadura citrea & IFO $14678^{\mathrm{T}}$ & U49001 \\
\hline Actinomadura coerulea & IFO $14679^{\mathrm{T}}$ & U49002 \\
\hline Actinomadura cremea subsp. rifamycini & IFO $14183^{\mathrm{T}}$ & U49003 \\
\hline Actinomadura echinospora & IFO $14042^{\mathrm{T}}$ & U49004 \\
\hline Actinomadura fulvescens & IFO $14347^{\mathrm{T}}$ & U49005 \\
\hline Actinomadura kijaniata & IFO $14229^{\mathrm{T}}$ & U49006 \\
\hline Actinomadura libanotica & IFO $14095^{\mathrm{T}}$ & U49007 \\
\hline Actinomadura luteofluorescens & IFO $13057^{\mathrm{T}}$ & U49008 \\
\hline Actinomadura macra & IFO $14102^{\mathrm{T}}$ & U49009 \\
\hline Actinomadura rugatobispora & IFO $14382^{\mathrm{T}}$ & $\mathrm{U} 49010$ \\
\hline Actinomadura verrucosospora & IFO $14100^{\mathrm{T}}$ & U49011 \\
\hline Microbispora aerata & ATCC $15448^{\mathrm{T}}$ & U48984 \\
\hline Microbispora amethystogenes & $\mathrm{JCM} 3021^{\mathrm{T}}$ & U48988 \\
\hline Microbispora chromogenes & IFO $14876^{\mathrm{T}}$ & U48989 \\
\hline Microbispora diastatica & IFO $14041^{\mathrm{T}}$ & U48990 \\
\hline Microbispora parva & ATCC $33326^{\mathrm{T}}$ & U48985 \\
\hline Microbispora thermodiastatica & ATCC $27098^{\mathrm{T}}$ & U14986 \\
\hline Microbispora thermorosea & ATCC $27099^{\mathrm{T}}$ & U48987 \\
\hline Microtetraspora africana & IFO $14745^{T}$ & U48842 \\
\hline Microtetraspora angiospora & IFO $13155^{\mathrm{T}}$ & $\mathrm{U} 48843$ \\
\hline Microtetraspora fastidiosa & IFO $14680^{T}$ & U48844 \\
\hline Microtetraspora ferruginea & IFO 14094 & U48845 \\
\hline Microtetraspora fusca & IFO $13915^{\mathrm{T}}$ & U48973 \\
\hline Microtetraspora glauca & IFO $14671^{\mathrm{T}}$ & U48974 \\
\hline Microtetraspora helvata & IFO $14681^{\mathrm{T}}$ & U48975 \\
\hline Microtetraspora niveoalba & IFO $15239^{\mathrm{T}}$ & U48976 \\
\hline Microtetraspora polychroma & IFO $14345^{\mathrm{T}}$ & U48977 \\
\hline Microtetraspora pusilla & IFO $14684^{\mathrm{T}}$ & U48978 \\
\hline Microtetraspora recticatena & IFO $14525^{\mathrm{T}}$ & U48979 \\
\hline Microtetraspora roseola & IFO $14685^{\mathrm{T}}$ & U48980 \\
\hline Microtetraspora salmonea & IFO $14687^{\mathrm{T}}$ & U48982 \\
\hline Microtetraspora spiralis & IFO $14097^{\mathrm{T}}$ & U48983 \\
\hline Streptosporangium comugatum & IFO $13972^{\mathrm{T}}$ & U48991 \\
\hline Streptosporangium fragile & IFO 14311 & U48992 \\
\hline Streptosporangium longisporum & IFO $13141^{\mathrm{T}}$ & U48993 \\
\hline Streptosporangium nondiastaticum & IFO $13990^{\mathrm{T}}$ & U48994 \\
\hline Streptosporangium pseudovulgare & IFO $13991^{\mathrm{T}}$ & U48995 \\
\hline Streptosporangium roseum & $\mathrm{JCM} 3005^{\mathrm{T}}$ & U48996 \\
\hline Streptosporangium violaceochromogenes & $\mathrm{JCM} 3281^{\mathrm{T}}$ & U48997 \\
\hline Streptosporangium vinidialbum & $\mathrm{JCM} 3027^{\mathrm{T}}$ & U48998 \\
\hline Streptosporangium vulgare & IFO $13985^{\mathrm{T}}$ & U48999 \\
\hline
\end{tabular}

\footnotetext{
$a_{\mathrm{T}}=$ type strain
}

Not $\mathrm{I}$. The ends of cloned $16 \mathrm{~S}$ ribosomal DNAs (rDNAs) were sequenced by using M13 forward sequencing primer 5'GTTTTCCCAGTCACGAC3' and reverse primer 5'GCGGATAACAATTTCACACAGG3'. The internal regions were sequenced in both orientations by using the following eight oligonucleotide primers whose target sequences were derived either from previous reports (9) or from an alignment of the 16S rRNA gene sequences of many actinomycete species: 5'GCCTATCAGCTTGTTGGT3' (nucleotides 239 to 256), 5'CGTGCC AGCAGCCGCGGT3' (nucleotides 514 to 531), 5'TAGATACCCTGGTAGTC C3' (nucleotides 789 to 806), 5'CCGCAACGAGCGCAACCC3' (nucleotides 1097 to 1114), 5'TACCGCGGC(G/T)GCTGGCAC3' (nucleotides 532 to 515), 5'GGACTACC(A/C/G)GGGTATCTAAT3' (nucleotides 806 to 787), 5'GGGT TGCGCTCGTTGCGG3' (nucleotides 1114 to 1097), and 5'ACGGGCGGTGT GTAC3' (nucleotides 1406 to 1392). All of the oligonucleotides were synthesized by Oligos Etc., Inc., Wilsonville, Oreg.

PCR amplification of 16S rRNA genes. Each PCR mixture contained $100 \mathrm{ng}$ of genomic DNA, $20 \mathrm{pmol}$ of each of the two universal primers, $200 \mu \mathrm{M}$ dATP, 200 $\mu \mathrm{M}$ dGTP, $200 \mu \mathrm{M}$ dCTP, $200 \mu \mathrm{M}$ dTTP, $2.5 \mathrm{U}$ of Taq DNA polymerase (Amersham, Aylesbury, Buckinghamshire, England), and $1 \times$ buffer (the buffer provided with the Taq DNA polymerase). The final volume was $100 \mu \mathrm{l}$. The PCR program was 25 cycles consisting of $95^{\circ} \mathrm{C}$ for $40 \mathrm{~s}, 52^{\circ} \mathrm{C}$ for $30 \mathrm{~s}$, and $72^{\circ} \mathrm{C}$ for 2 min. The PCR products were purified with a QIAquick Spin PCR purification kit
(QIAGEN GmbH, Hilden, Germany) and were quantified by using the FastCheck nucleic acid quantification system (GIBCO BRL Life Technologies, Gaithersburg, Md.).

Cloning and sequencing of $16 \mathrm{~S}$ rDNA. The purified PCR products of $16 \mathrm{~S}$ rRNA genes were cut with Not I (Amersham) and cloned into plasmid Bluescript SK (Stratagene, La Jolla, Calif.). E. coli DH5 $\alpha F^{\prime}$ cells (GIBCO BRL) were prepared and transformed as described previously (10). Recombinant clones were removed and grown in $2 \mathrm{ml}$ of Luria-Bertani (10) medium overnight, and the recombinant plasmid DNA was prepared by using a miniplasmid preparation kit (QIAGEN). Each cloned 16S rDNA was manually sequenced in both orientations by using an Amersham Sequenase kit (version 2.1).

Sequence alignment and phylogenetic analysis. Multiple alignments of sequences and calculations of levels of sequence similarity were carried out by using the CLUSTAL method (6) of the DNASTAR program (DNASTAR, Inc., Madison, Wis.). A phylogenetic tree was constructed by using the maximumparsimony method of the PAUP program (25) and the neighbor-joining analysis method of Saitou and Nei (21). The confidence level of the phylogenetic tree topology was evaluated by performing 100 bootstrap replications (heuristic search).

\section{RESULTS AND DISCUSSION}

Almost complete 16S rRNA gene sequences, corresponding to nucleotides 57 to 1491 of the E. coli 16S rRNA gene (2), were determined for the type strains of most species of the genera Microtetraspora, Microbispora, Streptosporangium, and Actinomadura (Table 1). The 16S rDNA sequences of several Streptosporangium species have been described previously (23), but these sequences contained segments with unknown bases and were 70 bases shorter than the other sequences which we determined. Therefore, we resequenced these 16S rRNA genes. Other than the regions that were absent from the previously described sequences, the two sets of sequences were nearly identical.

Levels of intra- and intergeneric 16S rDNA sequence similarity. Table 2 shows the pairwise levels of sequence similarity for all of the sequences which we studied. The seven Microbispora strains used in this study were among the strains of 10 species that were combined by Miyadoh et al. (11) into the single species Microbispora rosea on the basis of their high levels of DNA-DNA relatedness. The levels of similarity between the 16S rRNA sequences of these Microbispora strains ( 95.1 to $99.0 \%$ ) seem to support the hypothesis that this group is homogeneous. The intrageneric levels of sequence similarity for the members of the other genera appeared to vary over wider ranges, as follows: 91.8 to $98.4 \%$ for Microtetraspora strains, 86.1 to $98.9 \%$ for Streptosporangium strains, and 90.1 to $98.7 \%$ for Actinomadura strains. These values imply that each of these groups is heterogeneous. This conclusion is generally consistent with previous observations $(11,17,18,19,23)$. For example, the sequences of the 16S rRNA gene and the ribosomal AT-L30 protein of Streptosporangium corrugatum are known to differ substantially from the sequences of their counterparts in the type strains of Streptosporangium roseum, Streptosporangium nondiastaticum, and Streptosporangium pseudovulgare (17, 23). Significant differences in the relative electrophoretic mobilities of the AT-L30 proteins of Actinomadura strains have also been reported (18). The levels of 16S rRNA sequence similarity for the three original Microtetraspora species, Microtetraspora fusca, Microtetraspora glauca, and Microtetraspora niveoalba, are 97.9 to $98.4 \%$, but the levels of similarity with the species transferred from the former Actinomadura pusilla group are much lower ( 91.8 to $95.5 \%$ ), and when the intergeneric levels of sequence similarity were determined, we found high levels of similarity ( 93.7 to $96 \%$ ) between these three Microtetraspora species and Microbispora species. This observation seems to indicate that there is heterogeneity in the genus Microtetraspora.

An examination of the intra- and intergeneric sequence similarity values demonstrated that for the genera Microtetraspora, Microbispora, and Streptosporangium, species belonging to dif- 
TABLE 2. Levels of 16S rRNA gene sequence similarity for members of the genera Microbispora, Microtetraspora, Streptosporangium, and Actinomadura

\begin{tabular}{|c|c|c|c|c|c|c|c|c|c|c|c|c|c|c|c|c|c|c|c|c|}
\hline \multirow[b]{2}{*}{ Organism } & \multicolumn{20}{|c|}{$\% 16 \mathrm{~S}$ rRNA gene sequence similarity } \\
\hline & 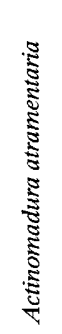 & 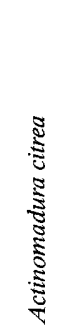 & 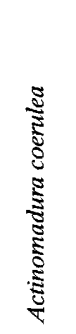 & 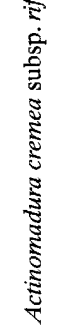 & 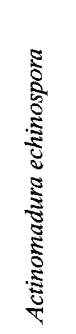 & 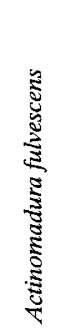 & 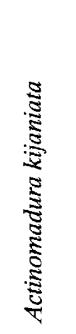 & 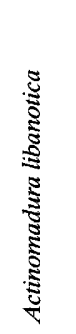 & 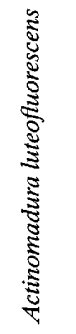 & 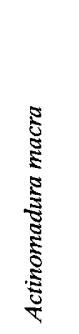 & 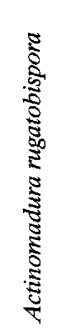 & 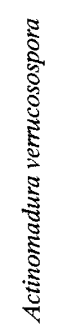 & 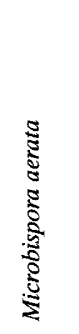 & 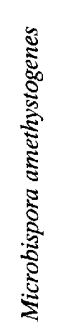 & 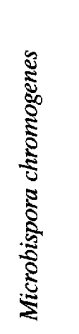 & 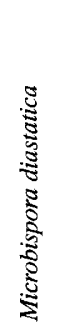 & 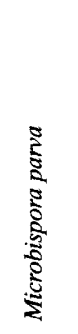 & 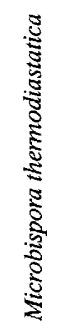 & 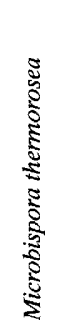 & 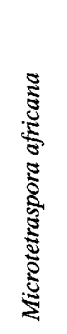 \\
\hline Actinomadura atramentaria & 100 & 93.3 & 93.2 & 91.8 & 92.6 & 93.1 & 93.9 & 91.5 & 93.6 & 93.9 & 93.9 & 93.1 & 89.6 & 90.1 & 89.4 & 89.1 & 89.5 & 89.4 & 88.9 & 89.4 \\
\hline Actinomadura citrea & & 100 & 97.4 & 94.1 & 93.5 & 95.2 & 94.8 & 91.3 & 97.7 & 95.2 & 94.8 & 96.9 & 89.6 & 89.3 & 89.1 & 88.8 & 88.7 & 89.4 & 88.2 & 89.5 \\
\hline Actinomadura coerulea & & & 100 & 93.5 & 93.4 & 94.7 & 94.7 & 91.2 & 98.2 & 95.6 & 95.5 & 97.7 & 89.6 & 89.4 & 89.2 & 88.8 & 88.8 & 89.6 & 88.2 & 89.6 \\
\hline Actinomadura cremea subsp. rifamycini & & & & 100 & 93.2 & 93.5 & 94.0 & 91.6 & 93.6 & 92.2 & 93.3 & 93.0 & 88.7 & 89.5 & 88.9 & 88.3 & 88.2 & 88.5 & 87.6 & 88.8 \\
\hline Actinomadura echinospora & & & & & 100 & 94.1 & 94.4 & 91.5 & 94.1 & 93.4 & 93.5 & 93.6 & 91.3 & 91.3 & 91.3 & 91.4 & 90.9 & 90.9 & 90.1 & 91.6 \\
\hline Actinomadura fulvescens & & & & & & 100 & 95.1 & 92.3 & 95.5 & 93.9 & 94.5 & 94.8 & 89.8 & 90.2 & 90.3 & 90.0 & 90.1 & 89.6 & 88.4 & 91.4 \\
\hline Actinomadura kijaniata & & & & & & & 100 & 92.9 & 95.3 & 93.4 & 94.7 & 94.8 & 89.4 & 89.1 & 89.6 & 89.5 & 88.9 & 89.1 & 88.6 & 90.6 \\
\hline Actinomadura libanotica & & & & & & & & 100 & 90.7 & 90.1 & 91.2 & 90.5 & 89.2 & 89.0 & 88.5 & 88.7 & 88.5 & 88.8 & 88.2 & 89.7 \\
\hline Actinomadura luteofluorescens & & & & & & & & & 100 & 95.2 & 95.4 & 98.7 & 89.4 & 89.1 & 89.1 & 88.8 & 88.5 & 89.4 & 88.4 & 89.6 \\
\hline Actinomadura macra & & & & & & & & & & 100 & 94.7 & 94.9 & 90.0 & 89.8 & 89.6 & 89.7 & 89.4 & 89.5 & 88.8 & 89.5 \\
\hline Actinomadura rugatobispora & & & & & & & & & & & 100 & 94.8 & 89.6 & 89.4 & 89.5 & 89.2 & 89.6 & 89.7 & 88.7 & 89.4 \\
\hline Actinomadura verrucosospora & & & & & & & & & & & & 100 & 89.0 & 88.7 & 88.7 & 88.2 & 88.0 & 89.0 & 87.8 & 89.1 \\
\hline Microbispora aerata & & & & & & & & & & & & & 100 & 96.8 & 96.3 & 96.3 & 97.4 & 99.2 & 97.7 & 92.6 \\
\hline Microbispora amethystogenes & & & & & & & & & & & & & & 100 & 97.9 & 97.8 & 98.1 & 96.5 & 95.1 & 93.4 \\
\hline Microbispora chromogenes & & & & & & & & & & & & & & & 100 & 99.0 & 97.5 & 96.0 & 96.3 & 93.3 \\
\hline Microbispora diastatica & & & & & & & & & & & & & & & & 100 & 97.2 & 96.0 & 96.1 & 93.4 \\
\hline Microbispora parva & & & & & & & & & & & & & & & & & 100 & 97.4 & 95.8 & 92.6 \\
\hline Microbispora thermodiastatica & & & & & & & & & & & & & & & & & & 100 & 97.5 & 92.3 \\
\hline Microbispora thermorosea & & & & & & & & & & & & & & & & & & & 100 & 91.4 \\
\hline Microtetraspora africana & & & & & & & & & & & & & & & & & & & & 100 \\
\hline Microtetraspora angiospora & & & & & & & & & & & & & & & & & & & & \\
\hline Microtetraspora fastidiosa & & & & & & & & & & & & & & & & & & & & \\
\hline Microtetraspora ferruginea & & & & & & & & & & & & & & & & & & & & \\
\hline Microtetraspora fusca & & & & & & & & & & & & & & & & & & & & \\
\hline Microtetraspora glauca & & & & & & & & & & & & & & & & & & & & \\
\hline Microtetraspora helvata & & & & & & & & & & & & & & & & & & & & \\
\hline Microtetraspora niveoalba & & & & & & & & & & & & & & & & & & & & \\
\hline Microtetraspora polychroma & & & & & & & & & & & & & & & & & & & & \\
\hline Microtetraspora pusilla & & & & & & & & & & & & & & & & & & & & \\
\hline Microtetraspora recticatena & & & & & & & & & & & & & & & & & & & & \\
\hline Microtetraspora roseola & & & & & & & & & & & & & & & & & & & & \\
\hline Microtetraspora salmonea & & & & & & & & & & & & & & & & & & & & \\
\hline Microtetraspora spiralis & & & & & & & & & & & & & & & & & & & & \\
\hline Streptosporangium corrugatum & & & & & & & & & & & & & & & & & & & & \\
\hline Streptosporangium fragile & & & & & & & & & & & & & & & & & & & & \\
\hline Streptosporangium longisporum & & & & & & & & & & & & & & & & & & & & \\
\hline Streptosporangium nondiastaticum & & & & & & & & & & & & & & & & & & & & \\
\hline Streptosporangium pseudovulgare & & & & & & & & & & & & & & & & & & & & \\
\hline Streptosporangium roseum & & & & & & & & & & & & & & & & & & & & \\
\hline Streptosporangium violaceochromogenes & & & & & & & & & & & & & & & & & & & & \\
\hline Streptosporangium viridialbum & & & & & & & & & & & & & & & & & & & & \\
\hline Streptosporangium vulgare & & & & & & & & & & & & & & & & & & & & \\
\hline
\end{tabular}

ferent genera often exhibit higher levels of sequence similarity than species belonging to the same genus (Table 2). Clearly, when the sequence similarity values are less than $95 \%$, they cannot be used to reliably assign a species to any of the three genera. The level of sequence similarity between these three genera and the genus Actinomadura is less than $92 \%$, which is lower than the levels of intrageneric similarity with only a few exceptions.
Stacketbrandt and Goebel (22) studied the correlation between 16S rRNA sequence analysis results and DNA-DNA reassociation results for defining bacterial species. These authors found that organisms that exhibited less than $97 \% 16 \mathrm{~S}$ rRNA sequence similarity did not have DNA-DNA reassociation values of more than $60 \%$ and should therefore be placed in different species. Miyadoh et al. (11) combined 10 Microbispora species into a single species, Microbispora rosea, on the 


\begin{tabular}{|c|c|c|c|c|c|c|c|c|c|c|c|c|c|c|c|c|c|c|c|c|c|}
\hline 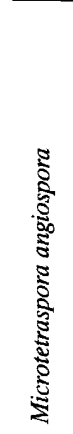 & 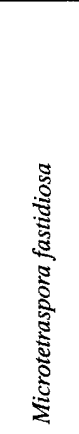 & 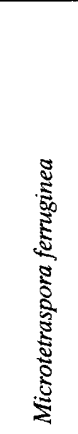 & 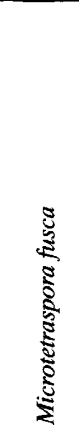 & 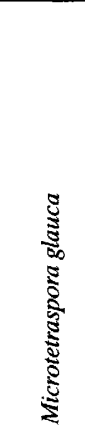 & 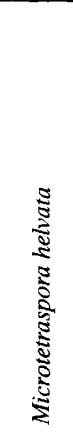 & 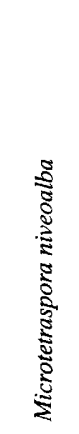 & 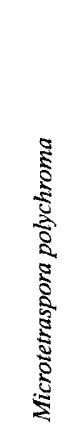 & 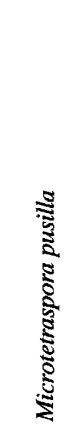 & 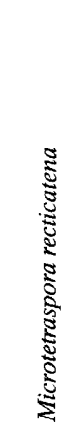 & 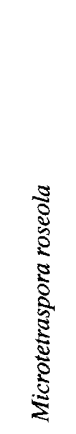 & 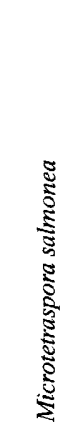 & 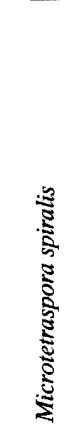 & 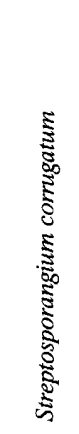 & 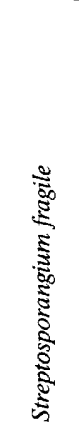 & 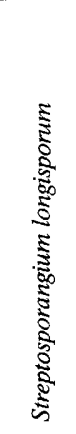 & 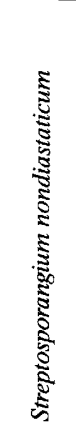 & 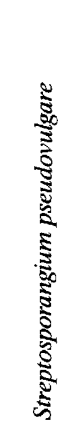 & 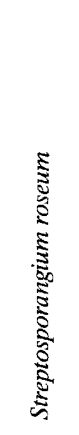 & 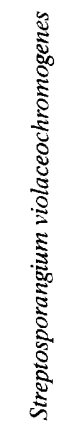 & 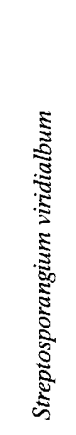 & 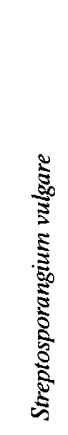 \\
\hline 88.3 & 88.4 & 88.6 & 88.8 & 88.9 & 89.9 & 88.9 & 89.4 & 89.6 & 89.0 & 89.0 & 88.3 & 88.4 & 88.4 & 88.9 & 89.2 & 88.1 & 88.6 & 89.1 & 88.8 & 88.8 & 90.1 \\
\hline 88.5 & 88.7 & 88.4 & 88.8 & 89.3 & 88.9 & 89.1 & 88.2 & 89.6 & 88.9 & 89.5 & 89.2 & 86.9 & 88.9 & 87.7 & 88.6 & 87.8 & 87.6 & 88.3 & 87.4 & 88.6 & 88.8 \\
\hline 88.7 & 88.5 & 89.1 & 88.5 & 89.1 & 89.4 & 88.9 & 88.6 & 89.9 & 88.9 & 89.6 & 89.4 & 87.3 & 89.1 & 86.9 & 88.9 & 88.2 & 88.0 & 88.4 & 88.0 & 88.7 & 88.9 \\
\hline 87.0 & 87.9 & 86.2 & 88.2 & 88.4 & 88.6 & 88.9 & 87.9 & 88.6 & 88.2 & 88.7 & 87.7 & 87.0 & 88.8 & 87.5 & 87.4 & 87.7 & 88.1 & 88.6 & 85.5 & 87.9 & 87.8 \\
\hline 89.6 & 90.4 & 90.0 & 90.9 & 91.0 & 91.3 & 90.9 & 90.9 & 90.9 & 91.0 & 91.4 & 89.9 & 89.4 & 91.0 & 89.6 & 89.8 & 90.5 & 90.1 & 90.8 & 87.4 & 90.0 & 90.3 \\
\hline 90.5 & 89.9 & 89.3 & 90.4 & 90.4 & 91.4 & 90.3 & 89.9 & 90.4 & 90.3 & 91.2 & 90.7 & 89.7 & 89.8 & 88.7 & 89.4 & 89.2 & 89.2 & 89.5 & 88.6 & 89.8 & 89.6 \\
\hline 89.6 & 88.6 & 89.0 & 89.1 & 89.5 & 90.2 & 89.6 & 89.1 & 90.5 & 90.0 & 90.6 & 89.8 & 88.7 & 89.5 & 89.5 & 89.9 & 89.5 & 89.8 & 89.9 & 89.4 & 90.8 & 90.2 \\
\hline 87.5 & 88.2 & 87.1 & 88.0 & 87.9 & 88.5 & 87.9 & 89.0 & 89.2 & 89.3 & 88.8 & 87.7 & 87.7 & 89.0 & 89.0 & 89.5 & 89.4 & 89.5 & 89.8 & 88.7 & 88.7 & 89.6 \\
\hline 88.7 & 88.6 & 89.1 & 88.4 & 88.9 & 89.4 & 88.9 & 88.6 & 89.9 & 89.0 & 89.6 & 89.2 & 87.3 & 89.1 & 86.9 & 89.0 & 88.1 & 87.9 & 88.6 & 87.7 & 88.6 & 88.9 \\
\hline 88.8 & 89.6 & 88.5 & 89.0 & 89.1 & 89.5 & 89.0 & 89.1 & 89.0 & 89.2 & 89.5 & 89.2 & 87.6 & 89.3 & 88.1 & 88.3 & 88.2 & 87.9 & 88.3 & 86.0 & 87.6 & 88.4 \\
\hline 87.8 & 88.3 & 86.0 & 88.5 & 88.8 & 88.9 & 88.8 & 88.7 & 89.3 & 88.8 & 88.7 & 88.0 & 87.3 & 89.7 & 87.7 & 87.8 & 88.0 & 88.1 & 88.3 & 86.1 & 88.6 & 88.2 \\
\hline 88.1 & 87.9 & 88.5 & 88.0 & 88.4 & 88.7 & 88.1 & 87.8 & 89.3 & 88.5 & 89.1 & 88.4 & 86.7 & 88.7 & 87.6 & 88.4 & 87.7 & 87.5 & 88.0 & 87.3 & 88.2 & 88.4 \\
\hline 92.3 & 93.6 & 92.3 & 95.0 & 95.0 & 93.7 & 95.3 & 93.5 & 92.6 & 92.6 & 91.9 & 91.9 & 91.5 & 94.5 & 91.2 & 91.5 & 91.5 & 91.9 & 91.7 & 91.3 & 92.3 & 92.2 \\
\hline 92.8 & 92.6 & 92.7 & 96.0 & 95.8 & 94.5 & 95.8 & 94.3 & 93.1 & 92.7 & 92.4 & 92.5 & 92.6 & 93.7 & 90.7 & 90.7 & 90.7 & 90.9 & 91.7 & 90.9 & 92.1 & 91.8 \\
\hline 93.5 & 92.8 & 92.6 & 95.3 & 95.9 & 94.8 & 95.5 & 93.6 & 94.3 & 92.6 & 92.7 & 92.8 & 93.6 & 93.2 & 92.1 & 91.2 & 91.7 & 91.9 & 90.8 & 91.6 & 93.3 & 91.6 \\
\hline 93.8 & 92.6 & 92.1 & 95.7 & 95.8 & 94.5 & 95.4 & 93.7 & 93.7 & 92.9 & 92.6 & 92.8 & 93.5 & 93.4 & 92.1 & 91.4 & 91.7 & 91.7 & 90.7 & 91.1 & 93.3 & 91.3 \\
\hline 92.3 & 92.1 & 92.5 & 95.0 & 95.1 & 94.3 & 94.9 & 93.4 & 92.7 & 92.0 & 92.1 & 91.6 & 92.1 & 93.7 & 90.9 & 90.9 & 90.4 & 90.8 & 91.1 & 90.9 & 92.1 & 91.8 \\
\hline 92.1 & 93.0 & 92.0 & 95.0 & 94.9 & 93.6 & 95.3 & 93.2 & 92.4 & 92.3 & 91.7 & 91.6 & 91.2 & 93.8 & 91.3 & 91.5 & 90.9 & 91.3 & 91.0 & 91.3 & 91.9 & 91.9 \\
\hline 91.8 & 93.0 & 90.9 & 93.7 & 94.1 & 92.8 & 94.4 & 92.1 & 92.6 & 91.4 & 90.8 & 91.7 & 91.4 & 93.0 & 91.4 & 91.0 & 91.2 & 91.8 & 90.0 & 89.0 & 92.3 & 90.9 \\
\hline 96.5 & 93.6 & 93.8 & 94.4 & 94.0 & 96.5 & 93.6 & 96.0 & 93.6 & 98.0 & 97.6 & 95.8 & 95.5 & 92.2 & 92.6 & 93.3 & 92.6 & 92.4 & 92.4 & 92.4 & 94.3 & 93.8 \\
\hline \multirow[t]{22}{*}{100} & 94.3 & 93.5 & 93.8 & 93.5 & 96.6 & 93.0 & 95.2 & 94.6 & 95.7 & 95.9 & 97.4 & 95.8 & 91.3 & 91.6 & 91.2 & 91.2 & 90.9 & 90.1 & 91.1 & 93.3 & 91.6 \\
\hline & 100 & 93.6 & 92.0 & 91.8 & 94.9 & 92.2 & 94.7 & 93.1 & 93.3 & 92.8 & 94.7 & 94.3 & 91.6 & 90.2 & 90.3 & 90.5 & 90.6 & 90.0 & 88.2 & 90.8 & 90.0 \\
\hline & & 100 & 92.6 & 92.8 & 94.9 & 92.9 & 95.0 & 94.7 & 93.1 & 93.4 & 94.1 & 94.5 & 92.1 & 91.5 & 91.6 & 90.5 & 90.8 & 90.9 & 90.9 & 91.7 & 92.7 \\
\hline & & & 100 & 98.4 & 94.6 & 97.9 & 94.3 & 93.6 & 93.6 & 93.1 & 92.7 & 93.3 & 94.0 & 91.9 & 93.1 & 91.9 & 92.1 & 92.1 & 92.3 & 93.6 & 93.1 \\
\hline & & & & 100 & 95.0 & 98.2 & 93.8 & 94.3 & 93.3 & 93.4 & 92.6 & 93.1 & 93.1 & 91.6 & 92.3 & 91.6 & 91.7 & 91.2 & 91.9 & 93.1 & 92.5 \\
\hline & & & & & 100 & 94.3 & 97.5 & 95.0 & 95.5 & 96.5 & 96.0 & 97.0 & 92.9 & 91.6 & 91.9 & 91.3 & 91.6 & 91.2 & 91.8 & 93.5 & 92.4 \\
\hline & & & & & & 100 & 93.8 & 94.0 & 93.4 & 93.0 & 92.6 & 92.8 & 93.0 & 91.2 & 92.2 & 91.6 & 91.7 & 91.3 & 91.5 & 93.1 & 92.5 \\
\hline & & & & & & & 100 & 94.1 & 95.3 & 94.5 & 95.0 & 95.9 & 93.1 & 91.1 & 91.6 & 91.3 & 91.4 & 91.8 & 91.2 & 92.4 & 92.4 \\
\hline & & & & & & & & 100 & 92.9 & 92.9 & 94.6 & 94.0 & 92.8 & 93.3 & 92.3 & 92.8 & 92.8 & 91.9 & 91.9 & 93.8 & 93.1 \\
\hline & & & & & & & & & 100 & 97.5 & 95.5 & 95.2 & 91.6 & 92.4 & 93.0 & 92.5 & 92.2 & 91.7 & 91.9 & 93.6 & 93.2 \\
\hline & & & & & & & & & & 100 & 95.1 & 94.4 & 91.4 & 92.3 & 93.1 & 91.7 & 91.9 & 91.5 & 92.0 & 93.5 & 93.4 \\
\hline & & & & & & & & & & & 100 & 95.6 & 90.8 & 91.7 & 91.9 & 91.0 & 90.9 & 89.7 & 90.9 & 93.1 & 91.6 \\
\hline & & & & & & & & & & & & 100 & 91.0 & 91.2 & 90.8 & 91.1 & 91.1 & 90.3 & 90.8 & 92.5 & 91.1 \\
\hline & & & & & & & & & & & & & 100 & 86.9 & 92.7 & 94.2 & 94.6 & 94.6 & 90.6 & 94.4 & 93.3 \\
\hline & & & & & & & & & & & & & & 100 & 96.7 & 96.0 & 96.1 & 95.5 & 95.6 & 95.6 & 96.7 \\
\hline & & & & & & & & & & & & & & & 100 & 95.2 & 95.6 & 96.0 & 95.3 & 95.2 & 98.2 \\
\hline & & & & & & & & & & & & & & & & 100 & 98.9 & 96.9 & 92.6 & 95.3 & 95.2 \\
\hline & & & & & & & & & & & & & & & & & 100 & 97.2 & 93.1 & 95.6 & 95.7 \\
\hline & & & & & & & & & & & & & & & & & & 100 & 92.3 & 94.8 & 96.9 \\
\hline & & & & & & & & & & & & & & & & & & & 100 & 93.9 & 95.3 \\
\hline & & & & & & & & & & & & & & & & & & & & 100 & 95.5 \\
\hline & & & & & & & & & & & & & & & & & & & & & 100 \\
\hline
\end{tabular}

basis of a mean DNA-DNA relatedness value of $56 \%$, and they also defined, on the basis of growth temperatures, two subspecies, Microbispora rosea subsp. rosea (including Microbispora chromogenes, Microbispora amethystogenes, Microbispora parva, and Microbispora diastatica used in this study) and Microbispora rosea subsp. aerata (including Microbispora aerata, $\mathrm{Mi}$ crobispora thermodiastatica, and Microbispora thermorosea). A total of 9 of the 21 similarity values obtained for the seven strains which we studied were less than $97 \%$, a finding which does not support the proposal that the 10 species should be combined in a single species. Ochi et al. (16) also found that the 10 Microbispora strains which they studied displayed substantially different AT-L30 ribosomal protein relative electrophoretic mobilities and thus raised doubts concerning the conclusions of Miyadoh et al. (11). It should be noted that the evidence that Miyadoh et al. used to combine the $10 \mathrm{Micro}$ - 


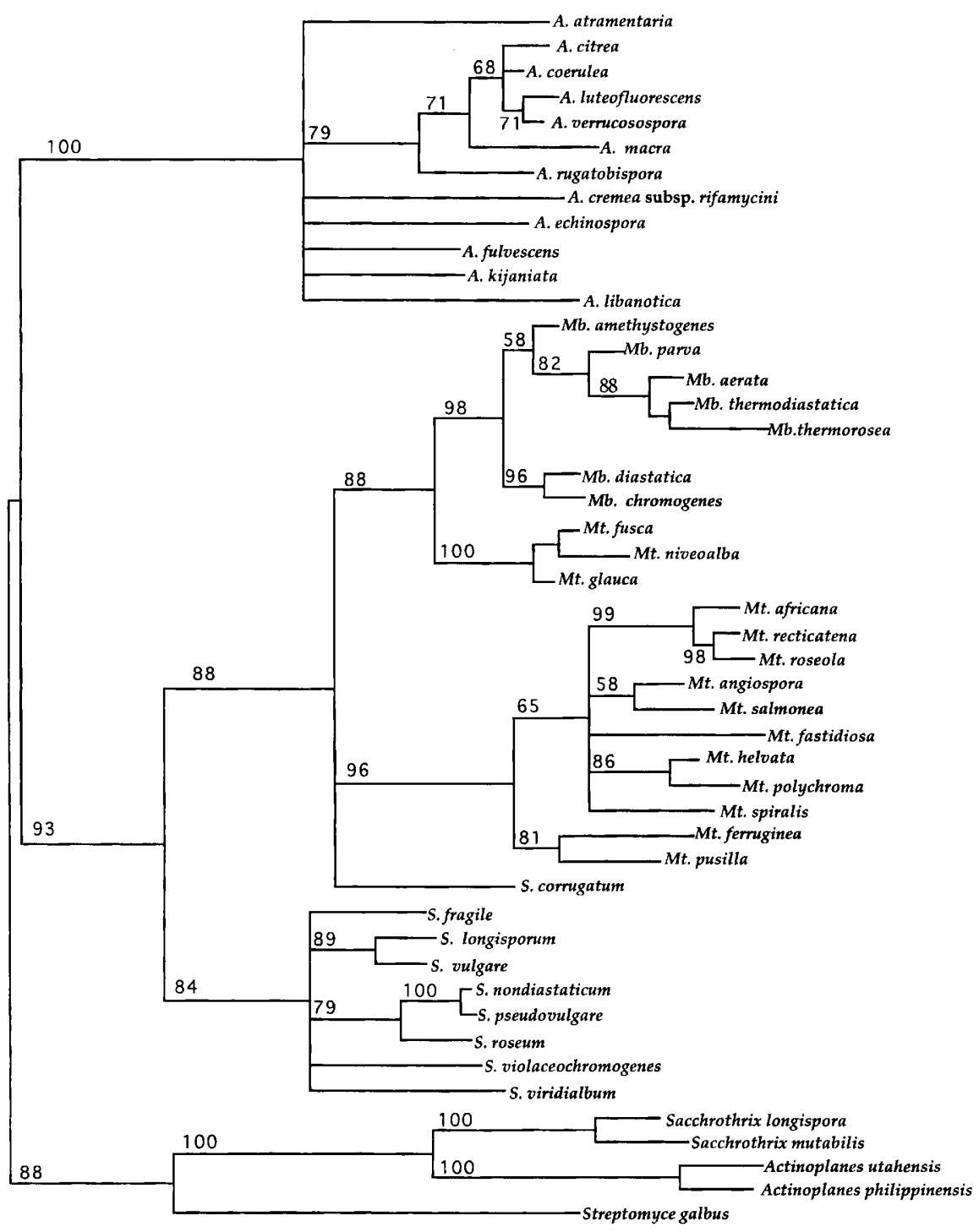

FIG. 1. Phylogenetic relationships among Actinomadura, Microtetraspora, Microbispora, and Streptosporangium species. The phylogenetic tree was generated by using a maximum-parsimony method (25) with gaps treated as a fifth base. When the gaps were excluded, the overall topology of the tree was not affected, except that the branch lengths were slightly different (data not shown). The numbers at nodes are bootstrap values (based on 100 resamplings). The bar represents one inferred substitution per 100 nucleotides. A phylogenetic tree having a similar topology was generated by using the Saitou-Nei (21) neighbor-joining method (data not shown). The 16S rRNA sequences of the following Streptomyces, Sacchrothrix, and Actinoplanes species were obtained from the EMBL database: Streptomyces galbus (accession number X793240), Sacchrothrix longispora (X76964), Sacchrothrix mutabilis (X76966), Actinoplanes utahensis (X80823), and Actinoplanes philippinensis (X72864). Abbreviations: A., Actinomadura; Mb., Microbispora; Mt., Microtetraspora; S., Streptosporangium.

bispora species seems to be weak, because 58 and 79 of the 90 DNA-DNA reassociation values obtained for the 10 strains were less than 60 and $70 \%$, respectively (11).

Phylogenetic relationships. All of the nucleotides of the $16 \mathrm{~S}$ rDNA sequences were included in our phylogenetic analysis without creating significant ambiguity in the multiple-sequence alignment. Our phylogenetic tree (Fig. 1) contains two major clusters, one consisting of Actinomadura species (the former Actinomadura madurae group species; the type species, $A$. madurae, was not included in this study because of difficulty in amplifying the complete $16 \mathrm{~S}$ rRNA gene by PCR) $(3,7)$ and the other consisting of the members of the genera Microtetraspora, Microbispora, and Streptosporangium. The Actinomadura cluster contains Actinomadura echinospora and Actinomadura rugatobispora, and thus our findings support the transfer of these two species from the genus Microbispora proposed by Miyadoh et al. (11). The bootstrap values determined for the two major clusters were 100 and $93 \%$, respectively. This result, in conjunction with the results of the sequence similarity analysis described above, supports the proposal that the genera Streptosporangium, Microtetraspora, and Microbispora should be included in the family Streptosporangiaceae $(4,8)$. The Streptosporangium species except Streptosporangium corrugatum and the Microtetraspora pusilla group species form two distinct subclusters. Although $S$. corrugatum exhibits relatively more affinity to the Microtetraspora pusilla cluster, its distance from each of the three subclusters is significant, which support the view that this species may merit status as a member of a separate 
genus (23). Microtetraspora glauca, which is the type species of the genus Microtetraspora, together with Microtetraspora fusca and Microtetraspora niveoalba, belong to a third distant subcluster which contains the members of the genus Microbispora. The bootstrap value for the branch point which separates the Microbispora subcluster from the Microtetraspora pusilla subcluster is significant $(88 \%)$.

The bootstrap values for phylogenetic separation of the three subclusters are more than $80 \%$. The phylogenetic distance between any two of the three subclusters is comparable to this value. If each of the subclusters represents a genus, obviously Microtetraspora glauca, Microtetraspora fusca, and Microtetraspora niveoalba cannot be accommodated with the members of the Microtetraspora pusilla group within the confines of one genus. Chemotaxonomic properties cannot be used to distinguish the genera Microtetraspora and Microbispora, and differentiation of these taxa has been based on a single morphological property, the number of spores in the spore chains (4). It is generally accepted that morphological characteristics alone are seldom reliable for determining taxonomic positions of bacterial species. However, in this case, a single morphological characteristic apparently plays a dominant role in the separation of two genera. None of the previous chemotaxonomic, numerical, and AT-L30 protein electrophoretic mobility studies included enough species belonging to both genera so that a comprehensive comparison could be performed $(1,7,16,18)$. However, by carefully scrutinizing the results of the previous reports, we obtained some evidence (as described above) which implied that the genus Microtetraspora is heterogeneous and that some Microtetraspora species and Microbispora species are closely related. This seemingly weak evidence became substantial when it was combined with the results of our phylogenetic analysis.

Conclusion. Our phylogenetic analysis based on nearly complete $16 \mathrm{~S}$ rDNA sequences clearly demonstrated that there are two distantly related clusters in the genus Microtetraspora and that three Microtetraspora species, represented by the type species of the genus, Microtetraspora glauca, are closely related to the genus Microbispora. Although the available evidence may not be sufficient to reclassify the genera Microbispora and Microtetraspora it shows that it will be necessary to carry out a comprehensive analysis in which chemotaxonomic and other approaches are used to redefine the taxonomic positions of these genera.

\section{ACKNOWLEDGMENTS}

This work was supported by the Institute of Molecular and Cell Biology.

We thank Michael Goodfellow for critically reading the manuscript.

\section{REFERENCES}

1. Athalye, M., M. Goodfellow, J. Lacey, and R. P. White. 1985. Numerical classification of Actinomadura and Nocardiopsis. Int. J. Syst. Bacteriol. 35: 86-98.

2. Brosius, J., J. J. Palmer, J. P. Kennedy, and H. F. Noller. 1978. Complete nucleotide sequence of a $16 \mathrm{~S}$ ribosomal gene from Escherichia coli. Proc. Natl. Acad. Sci. USA 75:4801-4805.

3. Goodfellow, M. 1989. Maduromycetes, p. 2509-2551. In S. T. Williams, M. E. Sharpe, and J. G. Holt (ed.), Bergy's manual of systematic bacteriology, vol. 4. The Williams \& Wilkins Co., Baltimore.

4. Goodfellow, M. 1992. The family Streptosporangiaceae, p. 1116-1138. In A. Balows, H. G. Trüper, M. Dworkin, W. Harder, and K.-H. Schleifer (ed.), The prokaryotes, 2nd ed. Springer-Verlag, New York.
5. Goodfellow, M., L. J. Stanton, K. E. Simpson, and D. E. Minnikin. 1990. Numerical and chemical classification of Actinoplanes and some related actinomycetes. J. Gen. Microbiol. 136:19-34.

6. Higgines, D. G., A. J. Bleasby, and R. Fuchs. 1992. CLUSTAL V: improved software for multiple sequence alignment. Comput. Appl. Biosci. 8:189-191.

7. Kroppenstedt, R., E. Stackebrandt, and M. Goodfellow. 1990. Taxonomic revision of the actinomycete genera Actinomadura and Microtetraspora. Syst. Appl. Microbiol. 13:148-160.

8. Kroppenstedt, R. M., and M. Goodfellow. 1992. The family Thermomonosporaceae, p. 1085-1114. In A. Balows, H. G. Trüper, M. Dworkin, W. Harder, and K.-H. Schleifer (ed.), The prokaryotes, 2nd ed. Springer-Verlag, New York.

9. Lane, D. J. 1991. 16S/23S rRNA sequencing, p. 115-175. In E. Stacketbrandt and $M$. Goodfellow (ed.), Sequencing and hybridization techniques in bacterial systematics. John Wiley \& Sons, Chichester, England.

10. Maniatis, T., E. F. Fritsch, and J. Sambrook. 1982. Molecular cloning: a laboratory manual. Cold Spring Harbor Laboratory, Cold Spring Harbor, N. Y.

11. Miyadoh, S., S. Amano, H. Tohyama, and T. Shomura. 1990. A taxonomic review of the genus Microbispora and a proposal to transfer two species to the genus Actinomadura and to combine ten species into Microbispora rosea. J. Gen. Microbiol. 136:1905-1913.

12. Miyadoh, S., H. Anzai, S. Amano, and T. Shomura. 1989. Actinomadura malachitica and Microtetraspora viridis are synonyms and should be transferred as Actinomadura viridis comb. nov. Int. J. Syst. Bacteriol. 39:152-158.

13. Nonomura, H., and Y. Ohara. 1971. Distribution of actinomycetes in soil. VIII. Green-spore group of Microtetraspora, its preferential isolation and taxonomic characteristics. J. Ferment. Technol. 49:1-7.

14. Nonomura, H., and Y. Ohara. 1971. Distribution of actinomycetes in soil. IX. New species of genera Microbispora and Microtetraspora, and their isolation method. J. Ferment. Technol. 49:887-894.

15. Ochi, K. 1992. Polyacrylamide gel electrophoresis analysis of ribosomal protein: a new approach for actinomycete taxonomy. Gene 115:261-265.

16. Ochi, K., K. Haraguchi, and S. Miyadoh. 1993. A taxonomic review of the genus Microbispora by analysis of ribosomal protein AT-L30. Int. J. Syst. Bacteriol. 43:58-62.

17. Ochi, K., and S. Miyadoh. 1992. Polyacrylamide gel electrophoresis analysis of ribosomal protein AT-L30 from an actinomycete genus, Streptosporangium. Int. J. Syst. Bacteriol. 42:151-155.

18. Ochi, K., S. Miyadoh, and T. Tamura. 1991. Polyacrylamide gel electrophoresis analysis of ribosomal protein AT-L30 as a novel approach to actinomycete taxonomy: application to the genera Actinomadura and Microtetraspora. Int. J. Syst. Bacteriol. 41:234-239.

19. Poshner, J., R. M. Kroppenstedt, A. Fischer, and E. Stackebrandt. 1985. DNA-DNA reassociation and chemotaxonomic studies on Actinomadura, Microbispora, Microtetraspora, Micropolyspora and Nocardiopsis. Syst. Appl. Microbiol. 6:264-270.

20. Rainey, F. A., J. Burgardt, R. M. Kroppenstedt, S. Klatte, and E. Stackebrandt. 1995. Phylogenetic analysis of the genera Rhodococcus and Nocardia and evidence for the evolutionary origin of the genus Nocardia from within the radiation of Rhodococcus species. Microbiology 141:523-528.

21. Saitou, N., and M. Nei. 1987. The neighbor-joining method: a new method for reconstructing phylogenetic trees. Mol. Biol. Evol. 4:406-425.

22. Stackebrandt, E., and B. M. Goebel. 1994. Taxonomic note: a place for DNA-DNA association and 16S rRNA sequence analysis in the present species definition in bacteriology. Int. J. Syst. Bacteriol. 44:846-849.

23. Stackebrandt, E., R. M. Kroppenstendt, K.-D. Jahnke, C. Kemmerling, and H. Gurtler. 1994. Transfer of Streptosporangium viridogriseum (Okuda et al. 1966), Streptosporangium viridogriseum subsp. kofuense (Nonomura and Ohara 1969), and Streptosporangium albidum (Furumai et al. 1968) to Kutzneria gen. nov. as Kutzneria viridogrisea comb. nov., Kutzneria Kofuensis comb. nov., and Kutzneria albida comb. nov., respectively, and emendation of the genus Streptosporangium. Int. J. Syst. Bacteriol. 44:265-269.

24. Stackebrandt, E., and C. R. Woese. 1991. Towards a phylogeny of the actinomycetes and related organisms. Curr. Microbiol. 5:197-202.

25. Swofford, D. L., and D. P. Begle. 1993. Phylogenetic analysis using parsimony, version 3.1, user's manual. Laboratory of Molecular Systematics, Smithsonian Institution, Champaign, Ill.

26. Thiemann, J. E., H. Pagani, and G. Beretta. 1968. A new genus of the Actinomycetales: Microtetraspora gen. nov. J. Gen. Microbiol. 50:295-303.

27. Woese, C. R. 1987. Bacterial evolution. Microbiol. Rev. 51:221-271.

28. Woese, C. R., O. Kandler, and M. L. Wheelis. 1990. Towards a natural system of organisms: proposal for the domains Archaea, Bacteria and Eucarya. Proc. Natl. Acad. Sci. USA 87:4576-4579.

29. Woese, C. R. E. Stackebrandt, T. J. Macke, and G. E. Fox. 1985. A phylogenetic definition of the major eubacterial taxa. Syst. Appl. Microbiol. 6:143-151. 